\title{
The 57th FCCA seminar/Forum and Annual Meeting for Young Glycoscientists 2008
}

\author{
第 57 回 FCCA セミナー/グライコサイエンス若手フォーラム 2008 開催報告
}

The FCCA seminar/Forum and Annual Meeting for Young Glycoscientists 2008 was held at Tsukuba Kenshu Center, managed by the Tsukuba-Gakuto-Shikin Foundation, Tsukuba City, on August 21-22, 2008. It was the third joint meeting of the "Forum for Young Glycoscientists" and "Annual Meeting for Young Glycoscientists," with 59 researchers attending the event. It comprised of 2 lectures, 11 oral and 27 poster presentations, and a fruitful discussion on various topics concerning glycoscience.

The first guest speaker was Prof. Kenichi Kasai from Faculty of Pharmaceutical Sciences, Teikyo University. His lecture, entitled "Origin and evolution of sugars," was about his "glyco-world hypothesis," according to which the first organisms on the primitive earth utilized the available saccharides as a source of energy and cell growth. His theory, based on the intrinsic features of glycochemistry, was very interesting. Additionally, on the basis of his long and extensive research experience, he emphasized the importance of communicating with other researchers.

The second lecture, entitled "Sugar phosphorylases and the metabolic pathway for human milk oligosaccharides in bifidobacteria," was presented by Dr. Shinya Fushinobu from Graduate School of Agricultural and Life Sciences, The University of Tokyo. He talked about the
FCCA セミナー/グライコサイエンス若手フォーラム 2008 が 2008 年 8 月 $21 \sim 22$ 日に財筑波学都資金財団 筑波研 修センター（茨城県つくば市）に拈いて開催されました。本 会は, 昨年同様「糖質若手フォーラム」と「グライコサイエ ンス若手の会」との合同開催集会であり，59名の糖鎖研究者 が参集しました。2 件の招待講演と 11 件の口頭発表ならびに 27 件のポスター発表が行われ, 糖鎖研究の有意義な議論が活 発に交わされる中, 盛況のうちに閉会となりました。

最初の招待講演は, 帝京大学・笠井献一先生に「糖はど のように発生し, どのように生命と共進化したのか?」という 演題で抢話し頂きました。原始地球に抢いて初期生命は, 身 近にかつ大量に存在した糖をエネルギー源および生体支持体 として利用したとするグライコワールド仮説を展開されまし た。糖化学に基づくその理論は大変興味深く, 非常に刺激を 受けました。また, これまで先生の豊富なご経験から, 研究 生活に掠いて人人とのコミュニケーションがいかに大切で あるかをお話くださいました。

招待講演抎二人目として, 東京大学大学院 - 伏信進矢先 生に「糖質ホスホリラーゼとビフィズス菌のヒトミルクオリ ゴ糖代謝」という題名で誩話し頂きました。アミノ酸配列に 基づいた糖質加水分解酵素の分類や, 酵素の構造, 機能およ び基質特異性の関連性などについてお話され, さらにドッキ

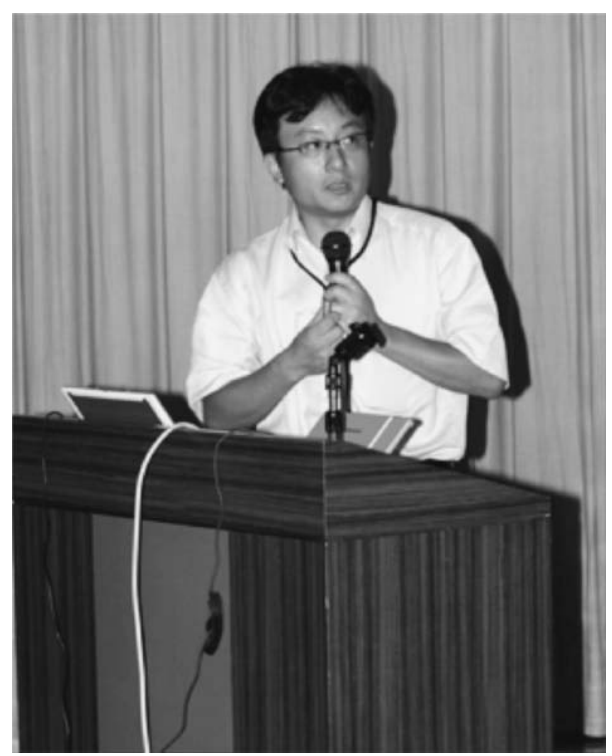

Dr. Fushinobu's lecture

Prof. Kasai's lecture 


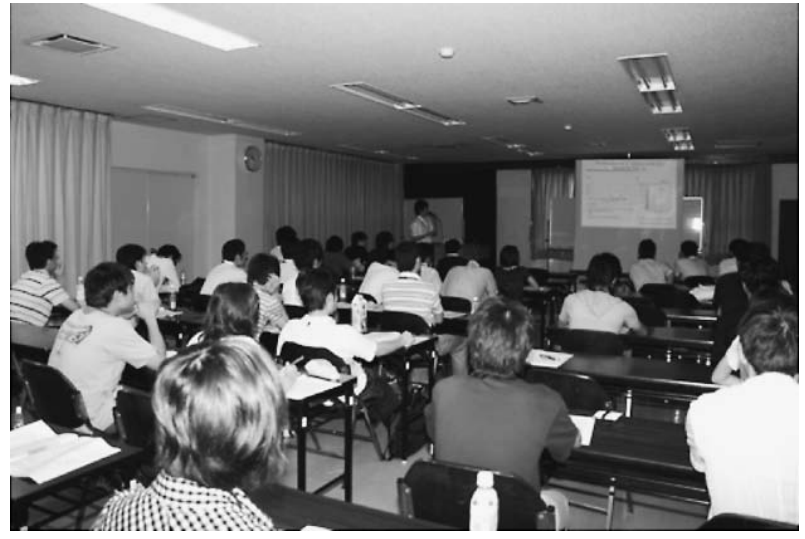

Oral session

classification of glycoside hydrolases based on amino acid sequence similarities and the relationship among structures, functions, and the substrate specificities of enzymes. $\mathrm{He}$ also gave a rather simple explanation of how to deal with molecular modeling such as docking simulation.

According to the two guest speakers, great discoveries are the result of honest and serious research. We need to adopt this attitude, which is crucial for conducting serious research.

In the oral and poster sessions, the speakers presented various topics based on sugar-related studies, such as (1) kinetic analysis of biomolecule by PET imaging using the rapid labeling method, (2) development of the functional materials using various saccharides, (3) rapid fluorous synthesis of monosaccharide unit in the microfluidic system, and (4) structural analysis of the carbohydrate recognition protein such as glycosidases and sugar ABC transporters. All the participants engaged in the discussion from broad perspectives. The poster session, held together with a mixer party on the first night, greatly helped the participants socialize with each other and engage in open discussions.

We are planning to hold a similar joint meeting of the Forum for Young Glycoscientists and Annual Meeting for Young Glycoscientists next year. Dr. Michiru Ida from Chubu University, in her capacity as a representative of the Annual Meeting for Young Glycoscientists, will be in charge of next year's meeting. We are looking forward to inviting many participants from academic establishments, companies, and national institutes. We strongly suggest that you visit our website given below to know more about our activities

http://www.geocities.jp/y_glycosci/

This seminar was supported by the FCCA and the Mizutani Foundation for Glycoscience, Japan.

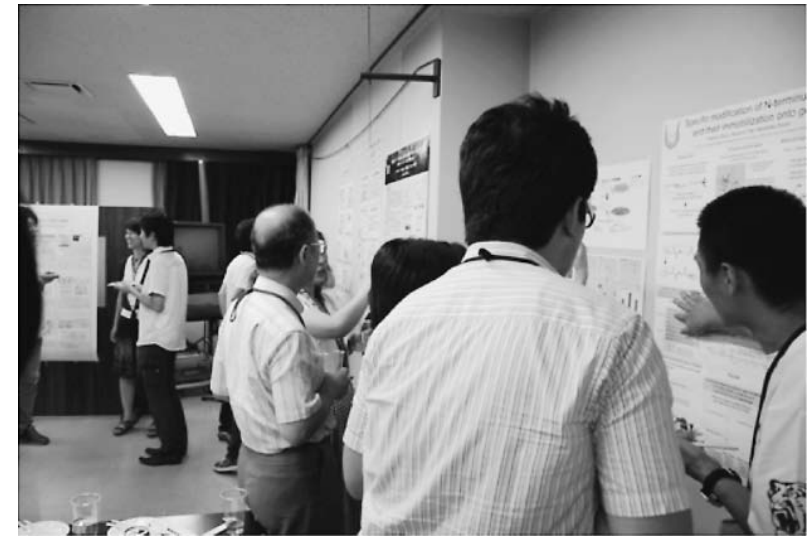

Poster session

ングシミュレーションなどの分子モデリングについても分か りやすくご説明いただきました。

また両先生の打話から，華やかな成果の裏には地道な実 験作業の積み重ねが隠れていることを伺い知ることができ， 我々若手研究者はこの重要な精神を肝に銘じるべきであると 改めて確認させて頂きました。

一般の口頭発表及びポスター発表では，(1)迅速ラベリン グ法を用いた PET イメージングによる様々な生体分子の動力 学解析，(2)糖を原料とした機能性材料の開発，(3)フルオラスマイクロフロー系による単糖ユニットの迅速合成などの新規 手法による糖鎖合成，(4)糖加水分解酵素やオリゴ糖トランス ポーターなどの糖認識性タンパク質の構造解析など, 最新の 技術を組み込んだ糖質科学について報告され，幅広い観点か らの議論がなされました。また，初日の夜に悶親会を兼效て 行われたポスター発表は, 参加者同士の交流を深めつつ, 忌 憚のない意見交換を交わす上で有意義なものでした。

来年度は, 初めて中部地区に抢いて, グライコサイエン ス若手フォーラムの開催を検討しており,グライコサイエン 又若手の会側は中部大学の伊田みちるが代表世話人を務めま す。大学, 企業, 公的研究所で活躍される若手糖質研究者の ご参加を抢待ち致しております。また，本会のホームページ も是非, ご覧頂けましたら幸いです。グライコサイエンス若 手フォーラム 2008 ホームページ : http://www.geocities.jp/y_ glycosci/

なお本セミナーは, FCCA 打よび財水谷糖質科学振興財 団からの助成を頂きました。 
Reported by

The Representative of the Forum for Young Glycoscientists:

HIGASHI, Nobuaki (Graduate School of Pharmaceutical Sciences, The University of Tokyo)

Organizer of Annual Meeting for Young Glycoscientists: NIHIRA, Takanori (National Food Research Institute) AMANO, Maho (Hokkaido University)

IDA, Michiru (Chubu University)

KOBAYASHI, Atsushi (Graduate School of Engineering, Tohoku University)

MATSUBARA, Teruhiko (Department of Biosciences and Informatics, Keio University)

MIURA, Yoshiko (Japan Advanced Institute of Science and Technology),

MIZUNO, Mamoru (Laboratory of Glyco-Organic Chemistry, The Noguchi Institute)

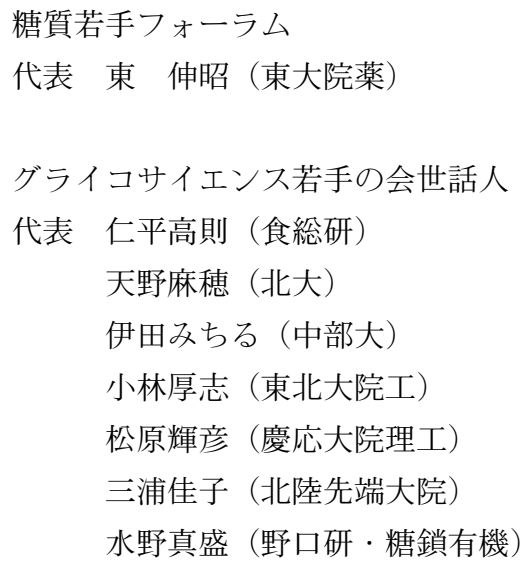

